\title{
Misused honorary authorship is no excuse for quantifying the unquantifiable
}

\author{
Murray J Dyck
}

\begin{abstract}
Correspondence to Dr Murray J Dyck, School of Applied Psychology, Griffith University, Gold Coast, Queensland 4222, Australia, m.dyck@griffith.edu.au
\end{abstract}

Received 9 August 2012 Accepted 10 August 2012

\begin{abstract}
Kovacs argues that honorary authorship and regarding each co-author of multi-authored papers as if they were sole authors when the performance of researchers is being evaluated by their publications mean that we should require authors to identify what proportion of each publication should be attributed to each co-author. Even if such attributions could be made reliably, such a change should not be made. Contributions to authorship cannot be validly quantified, and the relative merits of different publications are also neither equal nor validly quantifiable. Research administrators need to recognise that whatever criteria they adopt to evaluate the performance of researchers, researchers will find a way to game the system in order to maximise their personal benefit.
\end{abstract}

Kovacs ${ }^{1}$ highlights how the extent of a named author's contribution to a scholarly article cannot be inferred on the basis of inclusion as an author or position (ie, first, second, third, ... last) in the list of authors of a multi-authored publication. The list may include 'honorary authors' who have made no direct contribution to the work and may exclude 'ghost authors' who prepared the manuscript for publication. These inclusions and exclusions misrepresent the actual authorship of a work, and because the number of publications attributed to a person is commonly used to evaluate the person's performance as a researcher, they also inflate the performance ratings of people granted honorary authorship and deprive ghost authors of their due recognition.

The misuse of authorship counts to assess the researcher performance is an especial problem for Kovacs because some organisations do not take into account the number of authors who have made a contribution, and the extent of their contributions, to a publication. Articles that have two or three authors can receive double or triple the authorship credit of a single author paper. In this system, researchers who are not publishing as part of a large collaborative research group or as part of a publication cartel are likely to be seriously underacknowledged relative to their peers. It is in response to this issue that Kovacs proposes that authors attribute a numerical value to each co-author that defines their proportional contributions so that a more accurate authorship index can be created.

Kovacs is not the first person to suggest quantifying the extent of each author's contribution to a publication and guidelines for assigning a numerical value to each person's contribution have been proposed. ${ }^{2}$ Unfortunately, even if defining the proportion of a publication that was contributed by each author were a sensible thing to do, it is probably not something that could be done well. People's ability to self-report even relatively straightforward information like their grade point average $^{3}$ or hours worked ${ }^{4}$ is surprisingly poor, never mind their ability to make more emotionally charged estimates like those that husbands and wives make about the proportion of the housework that each has done. ${ }^{5-7}$ So how shall we apportion credit for an idea, or an impetus, or an argument? How shall we decide the value of a hunch that paid off compared with the time taken to evaluate the hunch?

The critical flaw with the Kovacs proposal is not, however, that estimates of authorial contributions will prove unreliable, but that it requires a change in how authorship is presented in order to solve a problem with the misuse of authorship and other bibliometric indices to assess the performance of researchers. And this means that even though the particular misuse that Kovacs provides as an example-treating authors of a multi-author paper as if they were the sole authors of the publication-is easily mitigated by taking into account the number of authors of each publication in the way that my own institution has done, ${ }^{8}$ such a change would also not overcome the problem. Research articles are not of equal value and scholarly publication is not necessarily the best-or even a very good-guide to a person's contribution to research. How, for example, should we judge the contributions of each of the thousands of people which made it possible, seemingly, to confirm the existence of the Higgs boson, and how can we compare each of those contributions with that made in preparing this article. Ultimately, such comparison would be a meaningless exercise, and just because research administrators are content to waste their time and ours in such an endeavour, there is no need for us to support their folly.

Even if the Kovacs proposal was not critically flawed, there would remain the problem that many researchers and institutions are as motivated to 'look good' as to 'be good' in fact. What consistently happens is that whatever criteria are used to define being good, people will find ways to apply those criteria in a way that is of most benefit to themselves. So if authorship or citations or other indices are used to assess researcher performance, researchers will find a way 'to game' the system. This was the recent experience in Australia when the government attempted to assess the relative performance in research of the universities. Thankfully, the attempt was eventually abandoned. ${ }^{9}$ 
Acknowledgements Thanks to Mark Boschen for his comments on a draft of this article.

\section{Competing interests None.}

Provenance and peer review Commissioned; internally peer reviewed.

\section{REFERENCES}

1. Kovacs $\mathbf{J}$. Honorary authorship epidemic in scholarly publications? How the current use of citation-based evaluative metrics make (pseudo)honorary authors from honest contributors of every multi-author article? J Med Ethics. Published Online First: 3 August 2012. doi:10.1136/medethics-2012-100568

2. Winston RB. A suggested procedure for determining order of authorship in research publications. J Couns and Dev 1985;63:515-18.

3. Kuncel NR, Crede M, Thomas LL. The validity of self-reported grade point averages, class ranks, and test scores: a meta-analysis and review of the literature. Rev Educ Res 2005;75:63-82.
4. Jacobs JA. Measuring time at work: are self-reports accurate? Month Lab Rev 1998;121:42-53.

5. Achen AC, Stafford JP. Data quality of housework hours in the panel study of income dynamics: who really does the dishes? Ann Arbor, MI: Institute for Social Research, University of Michigan, 2005. Technical Series Paper \#05-04.

6. Lee Y-S, Waite LJ. Husbands' and wives' time spent on housework: a comparison of measures. J Marr and Fam 2005;67:328-36.

7. Press JE, Townsley E. Wives' and husbands' housework reporting: gender, class, and social desirability. Gend and Soc 1998;12:188-218.

8. Griffith University. HERDC publication categories. http://www.griffith.edu.au/ research/research-services/research-policy-performance/herdc/ herdc-publication-categories (accessed 27 Jul 2012)

9. Gans J. Quelle surprise: academics gaming the system sank the ERA journal rankings. 2012. http://theconversation.edu.au/ quelle-surprise-academics-gaming-the-system-sank-the-era-journal-rankings-1575 (accessed 27 Jul 2012). 


\title{
JME
}

\section{Misused honorary authorship is no excuse for quantifying the unquantifiable}

\author{
Murray J Dyck
}

$J$ Med Ethics published online September 6, 2012

doi: 10.1136/medethics-2012-100939

Updated information and services can be found at:

http://jme.bmj.com/content/early/2012/09/06/medethics-2012-100939.full.html

\begin{tabular}{|c|c|}
\hline & These include: \\
\hline References & $\begin{array}{l}\text { This article cites } 5 \text { articles } \\
\text { http://jme.bmj.com/content/early/2012/09/06/medethics-2012-100939.full.html\#ref-list-1 }\end{array}$ \\
\hline $\mathbf{P}<\mathbf{P}$ & Published online September 6, 2012 in advance of the print journal. \\
\hline $\begin{array}{c}\text { Email alerting } \\
\text { service }\end{array}$ & $\begin{array}{l}\text { Receive free email alerts when new articles cite this article. Sign up in } \\
\text { the box at the top right corner of the online article. }\end{array}$ \\
\hline
\end{tabular}

Notes

Advance online articles have been peer reviewed, accepted for publication, edited and typeset, but have not not yet appeared in the paper journal. Advance online articles are citable and establish publication priority; they are indexed by PubMed from initial publication. Citations to Advance online articles must include the digital object identifier (DOIs) and date of initial publication.

To request permissions go to:

http://group.bmj.com/group/rights-licensing/permissions

To order reprints go to:

http://journals.bmj.com/cgi/reprintform

To subscribe to BMJ go to:

http://group.bmj.com/subscribe/ 